\title{
Competitive Carboxylate-Silicate Binding at Iron Oxyhydroxide Surfaces
}

\author{
Wei Cheng, Rémi Marsac, Khalil Hanna, and Jean-François Boily* \\ Cite This: Langmuir 2021, 37, 13107-13115 \\ Read Online
}

ABSTRACT: Dissolved silicate ions in wet and dry soils can determine the fate of organic contaminants via competitive binding. While fundamental surface science studies have advanced knowledge of binding in competitive systems, little is still known about the ranges of solution conditions, the time dependence, and the molecular processes controlling competitive silicate-organic binding on minerals. Here we address these issues by describing the competitive adsorption of dissolved silicate and of phthalic acid (PA), a model carboxylate-bearing organic contaminant, onto goethite, a representative natural iron oxyhydroxide nanomineral. Using surface complexation thermodynamic modeling of batch adsorption data and chemometric analyses of vibrational spectra,

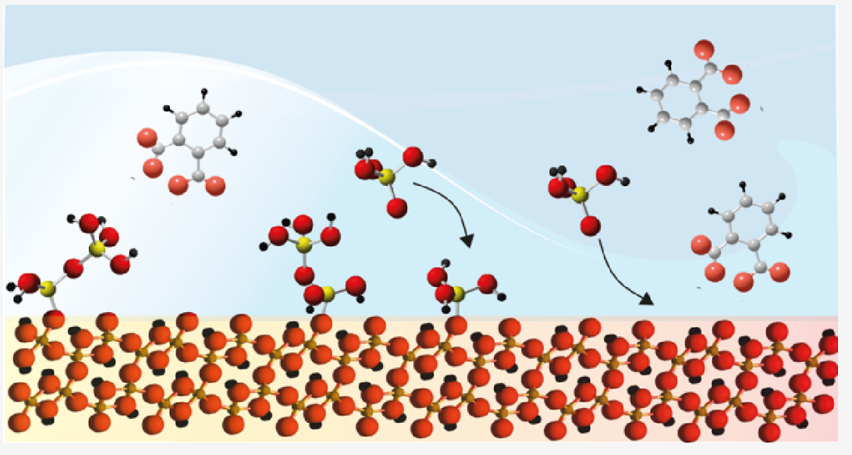
we find that silicate concentrations representative of natural waters $(50-1000 \mu \mathrm{M})$ can displace PA bound at goethite surfaces. Below $\mathrm{pH} \sim 8$, where PA binds, every bound Si atom removes $\sim 0.3 \mathrm{PA}$ molecule by competing with reactive singly coordinated hydroxo groups $(-\mathrm{OH})$ on goethite. Long-term $(30$ days $)$ reaction time and a high silicate concentration $(1000 \mu \mathrm{M})$ favored silicate polymer formation, and increased silicate while decreasing PA loadings. The multisite complexation model predicted PA and silicate binding in terms of the competition for - OH groups without involving PA/ silicate interactions, and in terms of a lowering of outer-Helmholtz potentials of the goethite surface by these anions. The model predicted that silicate binding lowered loadings of PA species, and whose two carboxylate groups are hydrogen- (HB) and metalbonded (MB) with goethite. Vibrational spectra of dried samples revealed that the loss of water favored greater proportions of $\mathrm{MB}$ over HB species, and these coexisted with predominantly monomeric silicate species. These findings underscored the need to develop models for a wider range of organic contaminants in soils exposed to silicate species and undergoing wet-dry cycles.

\section{INTRODUCTION}

Silicate is one of the most widely distributed major oxyanion in soils and natural waters. ${ }^{1}$ As a weathering product of silicate rocks, it is typically present at sub- to millimolar concentrations (e.g., $0.17-1.24 \mathrm{mM}){ }^{2}$ Silicate ions strongly adsorbed to mineral surfaces (e.g., iron oxyhydroxides, clays) can block reactive centers and thereby alter contaminant and element cycling and transport in nature. ${ }^{3-7}$ Although other naturally occurring anions (e.g., sulfate, phosphate) also have the ability to block reaction centers, silicate stands out for its ability to form polymeric coatings and for being an ion of widespread occurrence in natural waters. As such, understanding how silicates alter mineral surface site reactivity, ${ }^{3,8}$ including associated mineralogical transformations, ${ }^{9-11}$ is key to improving mass transport predictions in terrestrial and aquatic environments. Such predictions deserve a special focus on nanosized iron (oxyhydr)oxides given the reactivity and widespread occurrence of these particles in nature.

Silicate anions form strong metal-bonded (MB) species on minerals over a very broad range of $\mathrm{pH}$ values, a result of ligand exchange reactions involving surface hydroxo $(\mathrm{OH})$ groups (Figure 1). ${ }^{8,12-14}$ Species formed on a variety of iron (oxyhydr)oxide minerals (e.g., iron hydroxide, ${ }^{15}$ goethite, ${ }^{7,8,12,13,16}$ hematite, ${ }^{4,5,12}$ magnetite, ${ }^{3,6,12}$ and ferrihydrite $^{9,11,17-19}$ ) have previously been studied using vibrational spectroscopy $^{13,18,20,19}$ and molecular simulations. ${ }^{8,17,18}$ Moreover, the occurrence of these species can be predicted using surface complexation modeling. ${ }^{8,12,15-17}$ A model that we recently developed ${ }^{21}$ accounts for the $\mathrm{pH}$ and loading dependence of monomeric silicate species and their transformation to polymeric species. Considerably less is, however, known about (i) how silicate species impact the fate of other compounds-especially organic contaminants-competing for the same mineral surface sites, (ii) whether polymeric silicate species ${ }^{5,13,20}$ appearing over the course of a long reaction time (days to weeks) affect this competition, and (iii) how the loss

Received: August 24, 2021

Revised: October 12, 2021

Published: October 29, 2021 
(210)
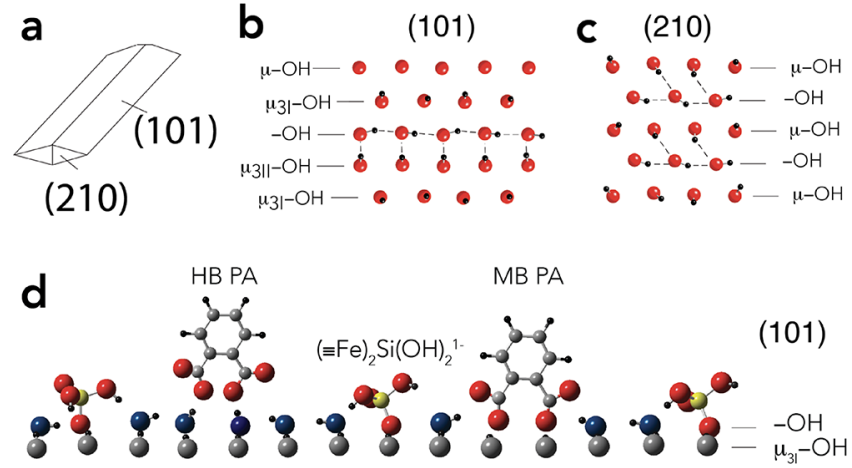

Figure 1. Schematic representation of (a) crystal habit and $(b-d)$ disposition of species and hydrogen bonding populations on dominant crystallographic faces of goethite. (a) Idealized crystal habit showing dominant (101) and (210) faces. (b, c) Disposition hydroxo groups on the (b) (101) and (c) (210) faces. See Song and Boily $^{41}$ for details. (d) Disposition of monomeric silicate species and PA along a row of $-\mathrm{OH}$ groups on the (101) face.

of interfacial waters through (episodic or cyclic) drying, which is typical of terrestrial environments (e.g., vadose zone of soils), affects the interfacial speciation. Understanding these competitive binding reactions is central to predicting the fate of compounds in terrestrial environments, where mineral surfaces are commonly exposed to silicate species.

Some of the better known competitive systems involve mixed oxyanions such as arsenic $c^{5,7,18,22}$ and selenium ${ }^{4,6}$ species. The literature reveals, for example, that monomeric surface silicate species effectively decrease arsenite ${ }^{7,18,22}$ and selenite ${ }^{4}$ loadings but negligibly affect arsenate loadings. ${ }^{18}$ Other studies that also have evaluated the effects of silicate polymerization on competitive binding reported contrasting findings. For example, Christl et al. ${ }^{5}$ reported that silicate polymers on hematite lower arsenite and arsenate binding, but Luxton et al. ${ }^{7}$ also reported that polymers do not significantly alter arsenite binding rates and loadings compared to monomers. Swedlund ${ }^{23}$ found, on the other hand, that monomeric silicate surface species inhibit arsenic adsorption to a greater extent than polymers. Of note, few studies used surface complexation models to quantify these competitive binding effects. Those that have $\mathrm{e}^{4,6,23}$ do not account for silicate polymers.

Along the same vein, there is a growing need to understand how silicates impact of fate of organic contaminants in nature, especially contaminants with the environmentally important carboxylate functional groups that target the same reactive $\mathrm{OH}$ binding sites as oxo functional groups of dissolved silicate species (Figure 1). For example, Rusch et al. ${ }^{24}$ found that salicylate binding to goethite-coated sand remobilized adsorbed silicate, and Roonasi et al. ${ }^{25}$ found that silicate had only a minor impact on magnetite-bound oleate but effectively reduced oleate loadings when magnetite was initially preequilibrated with silicate. Despite these types of efforts, little is still known about the range of solution conditions, the time dependence, and the molecular processes controlling these competitive reactions. To achieve this, knowledge of the coordination modes of silicate and carboxylate-bearing organic species is needed. This can be achieved by identifying ligands forming (i) metal-bonded ( $\mathrm{MB}$; inner-sphere (IS)), (ii) hydrogen-bonded ( $\mathrm{HB}$; direct $\mathrm{H}$-bond to surface (hydr)oxo group), or (iii) bound outer-sphere (OS; separated by at least one hydration sheath) complexes. Of note, the relative importance of these species is affected by $\mathrm{pH}(\mathrm{MB}$ at low and $\mathrm{HB} / \mathrm{OS}$ at high $\mathrm{pH}$ ), ionic strength ( $\mathrm{MB}$ at high and $\mathrm{HB}$ / OS at low ionic strength), as well as the interplay of mineral surface and ligand structures. Fundamental surface science studies on low molecular weight carboxylic acids, which are the focus of this work, have been particularly beneficial along this front. $^{26-34}$

Here, we address three leading issues-competitive binding, aging, and drying - by examining the competitive adsorption of silicate and a model carboxylic acid on goethite. We chose phthalic acid (PA; benzene-1,2-dicarboxylic acid) because it is a typical carboxylate- and phenyl ring-bearing soluble organic contaminant in soils and groundwater. PA has a strong capability for forming $\mathrm{MB}$ complexes with surface metal ions (e.g., $\mathrm{Fe}^{3+}$ on iron oxyhydroxides), and of forming $\mathrm{HB} / \mathrm{OS}$ surface complexes on minerals. ${ }^{34}$ Moreover, PA is an endocrine-disrupting agent ${ }^{35}$ that can originate from plastic debris, so its detection in soils, freshwater, and seawater ${ }^{36,37}$ raises grave environmental concerns. ${ }^{38,39}$ Goethite ( $\alpha$ $\mathrm{FeOOH}$ ) was, in turn, chosen as a representative iron oxyhydroxide for soils and sediments. ${ }^{40}$ Knowledge of dominant known crystal faces of synthetic goethite nanoparticles also facilitates the interpretation of plausible silicate and PA species, notably those disposed along rows of regularly spaced reaction centers on dominant crystallographic faces (Figure 1).

In this study, $\mathrm{pH}$ - and concentration-dependent silicate and PA loadings were investigated for 1 and 30 day reaction periods. This strategy allowed us to account for competitive effects resulting from monomeric silicate species formed at short reaction times compared to those exerted by polymeric silicate species, which appear over longer reaction times. Thermodynamic modeling of batch adsorption data and chemometric analyses and interpretations of vibrational spectra identified dominant molecular species of silicate and PA formed under wet conditions typical of water-saturated soils. Additionally, the spectra of dry goethite samples revealed how dehydration altered the molecular scale speciation of coexisting PA and silicate species. These observations are not only directly relevant to soils undergoing wet-dry cycling but also add further insight into the ever-growing literature ${ }^{42,26,43-49,27}$ on molecular-scale phenomena driving carboxylate-bearing organic ligand adsorption to mineral surfaces.

\section{MATERIALS AND METHODS}

2.1. Materials. All reagents were purchased from Sigma-Aldrich and used without further purification. All solutions were prepared with ultrapure water. The stock solution of silicate $(2 \mathrm{mM})$ was made from $\mathrm{Na}_{2} \mathrm{SiO}_{3} \cdot 9 \mathrm{H}_{2} \mathrm{O}$, and the stock solution of PA $(1 \mathrm{mM})$ was made from phthalic acid. Fourier transform infrared (FTIR) measurements in the $\mathrm{Si}-\mathrm{O}$ stretching region did not reveal any polymeric species in these stock solutions. This aligns with the solution work ${ }^{50}$ that shows that polymeric species form in solutions of larger silicate concentrations, as well as with our previous work ${ }^{13}$ that shows that polymeric species on goethite only appeared in solutions exceeding 2 $\mathrm{mM}$ silicate.

2.2. Goethite Synthesis and Characterization. Goethite was synthesized as in previous studies. ${ }^{28,51}$ Briefly, $400 \mathrm{~mL}$ of a $2.5 \mathrm{M}$ sodium hydroxide solution was titrated to $500 \mathrm{~mL}$ of a $0.5 \mathrm{M}$ ferric nitrate solution $\left(\mathrm{Fe}\left(\mathrm{NO}_{3}\right)_{3} \cdot 9 \mathrm{H}_{2} \mathrm{O}\right)$ at a fixed rate of $1 \mathrm{~mL} \mathrm{~min}^{-1}$ under constant stirring with a propeller, and under a steady stream of $\mathrm{N}_{2}(\mathrm{~g})$ to minimize contamination with dissolved (bi)carbonate species. The resulting slurry was aged at $60{ }^{\circ} \mathrm{C}$ for $72 \mathrm{~h}$ in an oven. Next, the precipitate was dialyzed (Spectra/Pore membrane 2) with Milli- $Q$ water. The water was changed every day until its conductivity 
Table 1. Surface Complexation Modeling Parameters

\begin{tabular}{|c|c|c|c|c|c|}
\hline aqueous solutions $^{a}$ & & & & & \\
\hline $\mathrm{PA}^{-2}+\mathrm{H}^{+} \rightleftharpoons \mathrm{PAH}^{-}$ & & & & & \\
\hline $\mathrm{PA}^{-2}+2 \mathrm{H}^{+} \rightleftharpoons \mathrm{PAH}_{2}$ & & & & & \\
\hline $\mathrm{H}_{4} \mathrm{SiO}_{4} \rightleftharpoons \mathrm{H}_{2} \mathrm{SiO}_{4}^{-}+\mathrm{H}^{+}$ & & & & & \\
\hline $\mathrm{H}_{4} \mathrm{SiO}_{4} \rightleftharpoons \mathrm{H}_{3} \mathrm{SiO}_{4}^{-2}+2 \mathrm{H}^{+}$ & & & & & \\
\hline $2 \mathrm{H}_{4} \mathrm{SiO}_{4} \rightleftharpoons \mathrm{Si}_{2} \mathrm{O}(\mathrm{OH})_{6}+\mathrm{H}_{2} \mathrm{O}$ & & & & & \\
\hline $2 \mathrm{H}_{4} \mathrm{SiO}_{4} \rightleftharpoons \mathrm{Si}_{2} \mathrm{O}_{2}(\mathrm{OH})_{5}{ }^{-}+\mathrm{H}^{+}+\mathrm{H}_{2} \mathrm{O}$ & & & & & \\
\hline surface reactions & $\log K$ & $\Delta z_{0}$ & $\Delta z_{1}$ & $\Delta z_{2}$ & ref \\
\hline$\equiv \mathrm{Fe}_{3} \mathrm{O}^{-0.5}+\mathrm{H}^{+} \rightleftharpoons \equiv \mathrm{Fe}_{3} \mathrm{OH}^{+0.5}$ & 9.1 & +1 & 0 & 0 & 28 \\
\hline$\equiv \mathrm{Fe}_{3} \mathrm{O}^{-0.5}+\mathrm{H}^{+}+\mathrm{Cl}^{-} \rightleftharpoons \equiv \mathrm{Fe}_{3} \mathrm{OH}^{+0.5 \ldots} \mathrm{Cl}^{-}$ & 8.1 & +1 & 0 & -1 & 28 \\
\hline$\equiv \mathrm{Fe}_{3} \mathrm{O}^{-0.5}+\mathrm{Na}^{+} \rightleftharpoons \equiv \mathrm{Fe}_{3} \mathrm{O}^{-0.5 \cdots} \mathrm{Na}^{+}$ & -1 & 0 & 0 & +1 & 28 \\
\hline$\equiv \mathrm{FeOH}^{-0.5}+\mathrm{H}^{+} \rightleftharpoons \equiv \mathrm{FeOH}_{2}^{+0.5}$ & 9.1 & +1 & 0 & 0 & 28 \\
\hline$\equiv \mathrm{FeOH}^{-0.5}+\mathrm{H}^{+}+\mathrm{Cl}^{-} \rightleftharpoons \equiv \mathrm{FeOH}_{2}^{+0.5 \ldots} \mathrm{Cl}^{-}$ & 8.1 & +1 & 0 & -1 & 28 \\
\hline$\equiv \mathrm{FeOH}^{-0.5}+\mathrm{Na}^{+} \rightleftharpoons \equiv \mathrm{FeOH}^{-0.5 \cdots \mathrm{Na}^{+}}$ & -1 & 0 & 0 & +1 & 28 \\
\hline $2 \mathrm{H}^{+}+2 \equiv \mathrm{FeOH}^{-0.5}+\mathrm{PA}^{-2} \rightleftharpoons(\equiv \mathrm{Fe})_{2}(\mathrm{PA})^{-}+2 \mathrm{H}_{2} \mathrm{O}$ & 14.8 & 0 & 0 & 0 & this study \\
\hline $2 \mathrm{H}^{+}+2 \equiv \mathrm{FeOH}^{-0.5}+\mathrm{PA}^{-2} \rightleftharpoons\left(\equiv \mathrm{FeOH}_{2}\right)_{2} \mathrm{PA}-$ & 19.5 & +2 & -2 & 0 & this study \\
\hline $2 \equiv \mathrm{FeOH}^{-0.5}+\mathrm{H}_{4} \mathrm{SiO}_{4} \rightleftharpoons(\equiv \mathrm{FeO})_{2} \mathrm{HSiO}_{2}^{-2}+\mathrm{H}^{+}+2 \mathrm{H}_{2} \mathrm{O}$ & $5.85^{b}(6.65)$ & 0.48 & -0.48 & 0 & 8 \\
\hline $2 \equiv \mathrm{FeOH}^{-0.5}+4 \mathrm{H}_{4} \mathrm{SiO}_{4} \rightleftharpoons(\equiv \mathrm{FeO})_{2} \mathrm{SiHSi}_{3} \mathrm{O}_{3}(\mathrm{OH})_{9}{ }^{-}+4 \mathrm{H}_{2} \mathrm{O}$ & $13.89^{b}(14.69)$ & 0.29 & -0.29 & 0 & 8 \\
\hline $2 \equiv \mathrm{FeOH}^{-0.5}+4 \mathrm{H}_{4} \mathrm{SiO}_{4} \rightleftharpoons(\equiv \mathrm{FeO})_{2} \mathrm{SiHSi}_{3} \mathrm{O}_{4}(\mathrm{OH})_{8}^{-2}+\mathrm{H}^{+}+4 \mathrm{H}_{2} \mathrm{O}$ & $6.6^{b}(8.27)$ & 0.29 & -1.29 & 0 & this study \\
\hline
\end{tabular}

${ }^{a} \log K$ values for aqueous solutions are from the minteq.v4 database in PHREEQC (version 2). ${ }^{55}{ }^{b} \log K$ values for 1 day reaction time (values for 30 days are provided between parenthesis).

was close to that of Milli- $Q$ water. The dialyzed suspensions were then stored in polypropylene containers at $4{ }^{\circ} \mathrm{C}$ until further use. $\mathrm{X}$ ray diffraction (XRD) confirmed goethite as the sole crystallographic solid phase (Figure S1), and FTIR spectroscopy revealed only the main vibrational bands of goethite (Figure S2). The $\mathrm{N}_{2}($ g)-B.E.T. specific surface area of goethite was $89 \pm 1 \mathrm{~m}^{2} \mathrm{~g}^{-1}$. The point of zero charge (PZC), previously determined by potentiometric titrations in $0.01,0.1$, and $1 \mathrm{M} \mathrm{NaCl}$ solutions at $298 \mathrm{~K}$, ${ }^{29}$ was 9.1.

2.3. Batch Adsorption Experiments. Aqueous suspensions of $50 \mathrm{~m}^{2} / \mathrm{L}$ goethite in $10 \mathrm{mM} \mathrm{NaCl}$ were equilibrated at $25^{\circ} \mathrm{C}$ with $\mathrm{PA}$ $(0-200 \mu \mathrm{M})$ with a range of silicate concentrations $(0-1 \mathrm{mM})$. The $\mathrm{pH}$ was maintained to the desired value $(4.0 \leq \mathrm{pH} \leq 10.0)$ by adding small volumes of $0.1 \mathrm{M} \mathrm{HCl}$ or $\mathrm{NaOH}$. The samples were then equilibrated on an end-to-end rotator at $25 \pm 1{ }^{\circ} \mathrm{C}$ for 1 or 30 days. These two reaction times were chosen based on previous timeresolved adsorption experiments, ${ }^{13}$ which revealed an initial rapid uptake of silicate and then substantially slower sorption rates. All suspension $\mathrm{pH}$ values were measured again before filtration $(0.2 \mu \mathrm{m}$ filter paper) with a benchtop $\mathrm{pH} / \mathrm{mV}$ meter (HI2211, HANNA Instrument) calibrated on a daily basis and with a resolution of 0.01 $\mathrm{pH}$. Final PA concentrations were analyzed by UV-vis spectrophotometry (Cary 5G UV-vis-NIR), and soluble silicate was determined using the molybdenum blue spectrophotometric method (detection limit of $1 \mu \mathrm{M}$ ). ${ }^{52}$ All experiments were repeated at least twice, with uncertainties in surface loadings of $\pm 5 \%$ for PA and $\pm 3 \%$ for silicate.

2.4. FTIR Spectroscopy. FTIR spectra of bound silicate and PA species were collected on $\mathrm{N}_{2}(\mathrm{~g})$-dried goethite powder after reaction in aqueous suspensions of $50 \mathrm{~m}^{2} / \mathrm{L}$ goethite with $\mathrm{PA}$ and silicate at $\mathrm{pH} 4.0$ or 6.0 for 1 day. The powder was produced by drying the centrifuged wet pastes of goethite under a stream of $\mathrm{N}_{2}(\mathrm{~g})(200 \mathrm{sccm}$, square cubic centimeter per minute) directly on an Attenuated Total Reflectance (ATR; diamond, single bounce; Golden Gate by Specac) cell for FTIR measurements. FTIR spectra were collected during the drying period until all $\mathrm{O}-\mathrm{H}$ stretching $\left(\sim 3400 \mathrm{~cm}^{-1}\right)$ and bending $\left(\sim 1630 \mathrm{~cm}^{-1}\right)$ modes of free water disappeared. FTIR spectra were continuously collected in situ with a Bruker Vertex 70/V FTIR spectrometer equipped with a DLaTGS detector. All spectra were collected in the $600-4000 \mathrm{~cm}^{-1}$ range at a resolution of $4.0 \mathrm{~cm}^{-1}$, and at a forward/reverse scanning rate of $10 \mathrm{~Hz}$. Each spectrum was an average of 250 scans, all taken over the course of $218 \mathrm{~s}$.

2.5. Multivariate Curve Resolution Analysis of FTIR Spectra. Spectral components representative of distinct molecular species of sorbed PA were extracted from the $1300-1900 \mathrm{~cm}^{-1}$ region of spectra of goethite samples equilibrated over a range of PA surface loadings at $\mathrm{pH} 4$ and 6. This chemometric analysis, built on Multivariate Curve Resolution Alternating Least Square (MCR-ALS), ${ }^{53}$ was implemented with a new code written for this study using MATLAB 2016b (MathWorks, Inc.). As in MCR-ALS, ${ }^{53}$ we applied the Beer-Lambert law $\left(\mathbf{A}_{m \times n}=\boldsymbol{\varepsilon}_{m \times k} \mathbf{C}_{k \times n}\right)$ to extract $k$ spectral components $(\boldsymbol{\varepsilon} \geq 0)$ and their correlated concentrations $\left(\mathbf{C}_{k \times n} \geq 0\right)$ from a matrix of experimental absorbance $\left(\mathbf{A}_{m \times n}\right)$ data collected over $m$ wavenumbers and $n$ samples. In essence, the program iteratively rotates the first $k$ orthogonal singular vectors (cf. eigenvectors) into a real chemical space conforming to these constraints $\left(\boldsymbol{\varepsilon}_{m \times k} \geq 0, \mathbf{C}_{k \times n} \geq 0\right)$ to minimize the sum of squares of the deviation of the model from the experimental A data. In our new implementation of this approach, however, we selectively fixed $\boldsymbol{\varepsilon}$ values of PA species in noncompetitive systems to search for new species in the competitive Si-bearing system. This approach ensured that the inherent spectral profiles of PA species were not conflated with those of new, or poorly resolved, species.

2.6. Surface Complexation Modeling. The multisite complexation (MUSIC) model $^{54}$ and the geochemical speciation code PHREEQC (version 2) ${ }^{55}$ were used for surface complexation calculations. The charge of the goethite/water interface was treated using the three-plane model (TPM) for the electric double layer (EDL). Charges of the adsorbates were distributed among the 0- $\left(\mathrm{H}^{+}\right.$ metal-bonded PA and silicate), 1- (hydrogen-bonded PA and nonbonded portions of silicates), and 2- $\left(\mathrm{Na}^{+}, \mathrm{Cl}^{-}\right)$planes. Singly (三 $\left.\mathrm{FeOH}^{-0.5} ;-\mathrm{OH}\right)$, doubly $\left(\equiv \mathrm{Fe}_{2} \mathrm{OH} ; \mu-\mathrm{OH}\right)$, and triply (三 $\left.\mathrm{Fe}_{3} \mathrm{OH}^{+0.5} ; \mu_{3}-\mathrm{O}(\mathrm{H})\right)$ coordinated oxygens outcrop the goethite surface, depending on the crystal face (Figure 1) and $\mathrm{pH}$. The protonation of these species was predicted using a simplified 1-pK model, here neglecting the contributions of doubly and part of the triply coordinated oxygens. The reactive site density in this model was detailed in our previous work ${ }^{28,29}$ and includes 3.12 sites $\mathrm{nm}^{-2}$ of $\equiv$ $\mathrm{FeOH}^{-0.5}$ and 3.12 sites $\mathrm{nm}^{-2}$ of $\equiv \mathrm{Fe}_{3} \mathrm{O}^{-0.5}$ on the (101) plane $(90 \%$ of the surface area). Additionally, it includes 7.4 sites $\mathrm{nm}^{-2}$ of $\equiv$ $\mathrm{FeOH}^{-0.5}$ on the (210) plane (10\% of the surface area). These goethite faces pertain to the Pmab space group. Equilibrium constants of all surface species are reported in Table 1.

\section{RESULTS AND DISCUSSION}

Silicate competitively binds with $\mathrm{PA}$ below $\mathrm{pH} \sim 8$, where $\mathrm{PA}$ is adsorbed (Figure 2a,b). This occured at silicate concentrations 

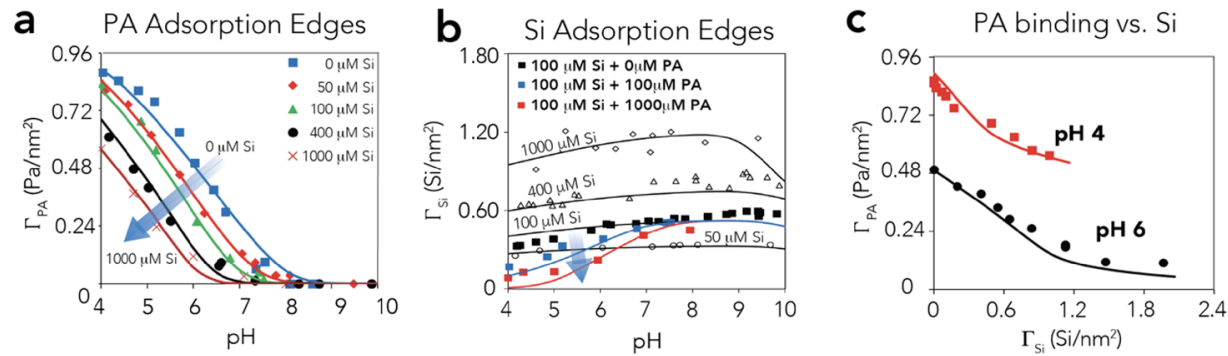

Figure 2. Phthalate $\left(\Gamma_{\mathrm{PA}}\right.$; PA species per $\left.\mathrm{nm}^{2}\right)$ and silicate $\left(\Gamma_{\mathrm{Si}} ; \mathrm{Si}^{4+}\right.$ per $\left.\mathrm{nm}^{2}\right)$ loadings achieved after 1 day of reaction in $50 \mathrm{~m}^{2} / \mathrm{L}$ goethite suspensions in $10 \mathrm{mM} \mathrm{NaCl}$ at $298 \mathrm{~K}$. (a) PA adsorption edges in goethite suspensions of $100 \mu \mathrm{M} \mathrm{PA}$ with $0-1000 \mu \mathrm{M}$ silicate. (b) Silicate adsorption edges in separate $(0-1000 \mu \mathrm{M}$ silicate) and competitive (0-1000 $\mu \mathrm{M} \mathrm{PA})$ systems. (c) PA loadings at pH 4 and 6 in relation to bound silicate obtained from suspensions with $100 \mu \mathrm{M}$ PA and $0-1000 \mu \mathrm{M}$ silicate. All lines are predictions are from the SCM of this study. $\Gamma$ denotes surface loadings in terms of PA species per $\mathrm{nm}^{2}\left(\Gamma_{\mathrm{PA}}\right)$ and $\mathrm{Si}^{4+}$ per $\mathrm{nm}^{2}\left(\Gamma_{\mathrm{Si}}\right)$.
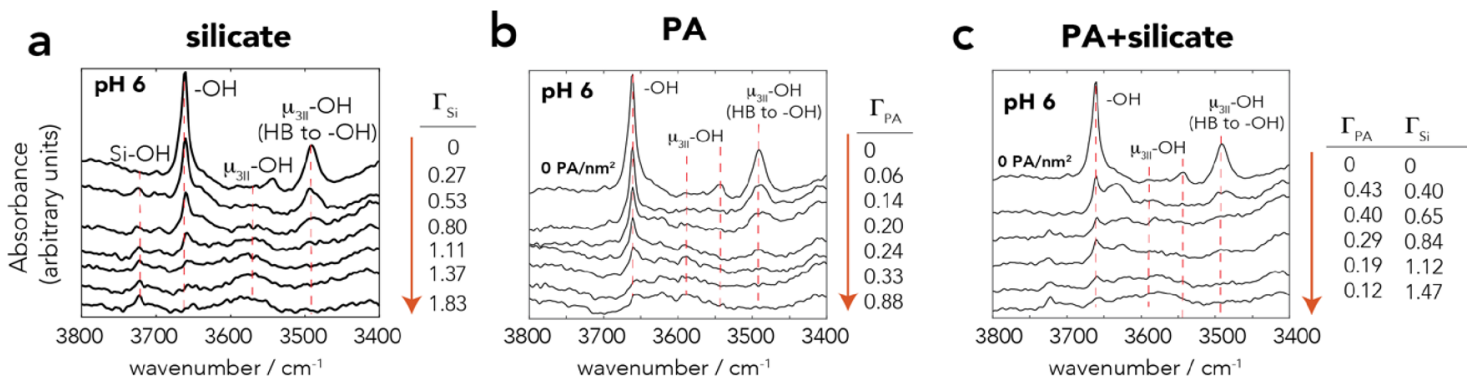

Figure 3. FTIR spectra of the $\mathrm{O}-\mathrm{H}$ stretching region of the surface $\mathrm{OH}$ group and of $\mathrm{Si}-\mathrm{OH}$ groups at the goethite surface. The spectra were obtained after 1 day of reaction with (a) silicate, (b) PA, and (c) silicate and PA in aqueous suspensions of $50 \mathrm{~m}^{2} / \mathrm{L}$ goethite in $10 \mathrm{mM} \mathrm{NaCl}$ at $298 \mathrm{~K}$ by drying centrifuged wet goethite pastes with a flow of $\mathrm{N}_{2}(\mathrm{~g})$ on the ATR cell at $298 \mathrm{~K}$. Here, the dominant $3661 \mathrm{~cm}^{-1}$ band of the exchangeable $-\mathrm{OH}$ group was removed by PA and silicate binding. The loss of $-\mathrm{OH}$ altered the hydrogen bonding environment of unreacted $-\mathrm{OH}$ groups, and removed pre-existing accepting hydrogen bonds from neighboring $\mu_{3}-\mathrm{OH}$ sites (Figure 1). Si-OH groups of bound silicate species were detected at $\sim 3710 \mathrm{~cm}^{-1}$. All band intensities were normalized from the bulk $\mathrm{O}-\mathrm{H}$ stretching band of goethite at $3120 \mathrm{~cm}^{-1}$ (Figure S2). $\Gamma$ denotes surface loadings in terms of PA species per $\mathrm{nm}^{2}\left(\Gamma_{\mathrm{PA}}\right)$ and $\mathrm{Si}^{4+}$ per $\mathrm{nm}^{2}\left(\Gamma_{\mathrm{Si}}\right)$.

representative of natural waters $(50-1000 \mu \mathrm{M})$. PA adsorption edges were, as a result, effectively shifted to lower $\mathrm{pH}$ values (Figure 2a), and were associated to the loss of $\sim 0.3$ PA per sorbed silicate species at both $\mathrm{pH} 4$ and 6 (Figure 2c).Silicate binding was, in turn, lowered below $\mathrm{pH} \sim 8$ from the competition of PA binding for reactive $-\mathrm{OH}$ groups (Figure $2 \mathrm{~b})$. We also note that the sum of PA $\left(\Gamma_{\mathrm{PA}}, \mathrm{PA} / \mathrm{nm}^{2}\right)$ and (mono- or polymeric) silicate loadings $\left(\Gamma_{\mathrm{Si}} \mathrm{Si}^{4+} / \mathrm{nm}^{2}\right)$ never exceeded the density $\left(3.5\right.$ sites $\left./ \mathrm{nm}^{2}\right)$ of reactive $-\mathrm{OH}$ groups involved in PA and silicate binding (Figure 1).

3.1. Modeling. To develop a predictive model for this competitive system, we recalibrated literature $8,17,30,31$ SCM models for silicate and PA binding on goethite using the precise solution conditions, and surface complexation modeling framework chosen for this study. This approach was necessary to ensure that any thermodynamic predictions and molecular-based interpretations from subsystems were accurate for the multicomponent, competitive system, under study. Therefore, we begin by briefly describing these models, as they are needed to aid our discussion of competitive silicate and PA binding.

To predict silicate binding, we used our recent silicatebinding model (Table 1 ). ${ }^{21}$ The model captures the broad $\mathrm{pH}$ and strong binding affinity of silicate on goethite (Figure $2 \mathrm{~b}$ and Figure S3). ${ }^{8,12,14}$ Building on Kanematsu et al., ${ }^{13}$ we were able to use the model to predict silicate binding by a ligand exchange reaction with $-\mathrm{OH}$ sites (Figure 1). These binding modes align with new sets of FTIR spectra (Figure 3a for $\mathrm{pH} 6$ and Figure S4 for $\mathrm{pH} 4$ ) of dried samples, revealing the preferential consumption of their signature $3661 \mathrm{~cm}^{-1}$ band alongside the disruption of hydrogen bonds with the neighboring $\mu_{3 \mathrm{II}} \mathrm{OH}$ group $\left(3490 \mathrm{~cm}^{-1}\right)$. These spectra also showed that the resulting silicate surface complex exposed $\mathrm{Si}-$ $\mathrm{OH}$ groups through another signature band at $\sim 3720 \mathrm{~cm}^{-1}$. As Kanematsu et al. ${ }^{13}$ also suggested that monomeric silicate complexes form a hydrogen bond with the neighboring $-\mathrm{OH}$ site (Figure 1), we modeled silicate binding using the reaction $\left(\log \mathrm{K}(\equiv \mathrm{FeO})_{2} \mathrm{Si}(\mathrm{OH})_{2}^{-}\right)$.

$$
\begin{aligned}
2 & \equiv \mathrm{FeOH}^{0.5-}+\mathrm{Si}(\mathrm{OH})_{4}{ }^{0} \\
& \rightleftharpoons(\equiv \mathrm{FeO})_{2} \mathrm{Si}(\mathrm{OH})_{2}{ }^{-}+2 \mathrm{H}_{2} \mathrm{O}
\end{aligned}
$$

Therefore, this reaction aligns with previous models for a bidentate surface complex, ${ }^{8,17}$ although it uses a charge distribution scheme (Table 1) for a hydrogen-bonded monodentate inner-sphere complex. The model also accounts for polymeric species to predict binding at greater silicate loadings, for example, those exceeding $\sim 1.5 \mathrm{Si}^{4+}$ per $\mathrm{nm}^{2}$ where additional silicate loadings did not decrease PA loadings (Figure $2 \mathrm{c}$ ). ${ }^{32}$ These polymeric species were detected by FTIR spectroscopy (Figure 4a). For practical modeling reasons, ${ }^{8}$ these species were expressed solely through tetrameric species with $\left(\log \mathrm{K}(\equiv \mathrm{FeO})_{2} \mathrm{SiHSi}_{3} \mathrm{O}_{3}(\mathrm{OH})_{9}{ }^{-}\right)$and $(\log \mathrm{K}(\equiv$ $\left.\mathrm{FeO})_{2} \mathrm{SiHSi}_{3} \mathrm{O}_{4}(\mathrm{OH})_{8}^{-2}\right)$ :

$$
\begin{aligned}
2 & \equiv \mathrm{FeOH}^{-0.5}+4 \mathrm{Si}(\mathrm{OH})_{4}{ }^{0} \\
& \rightleftharpoons(\equiv \mathrm{FeO})_{2} \mathrm{SiHSi}_{3} \mathrm{O}_{3}(\mathrm{OH})_{9}{ }^{-}+4 \mathrm{H}_{2} \mathrm{O}
\end{aligned}
$$



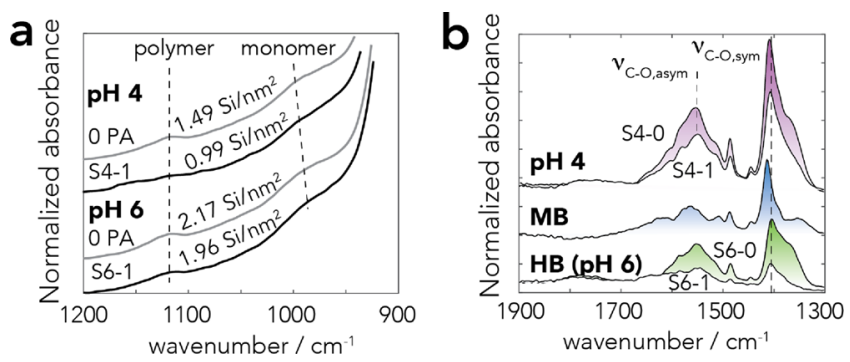

Figure 4. FTIR spectra of the (a) $\mathrm{Si}-\mathrm{O}$ stretching region and (b) C$\mathrm{O}$ stretching region of centrifuged wet goethite pastes at $\mathrm{pH} 4$ and 6 in noncompetitive $\left(0 \mathrm{PA}=0 \mathrm{PA} / \mathrm{nm}^{2} ; \mathrm{S} 4-0=0.86 \mathrm{PA} / \mathrm{nm}^{2}\right.$; $\mathrm{S} 6-0=$ $\left.0.50 \mathrm{PA} / \mathrm{nm}^{2}\right)$ and competitive $\left(\mathrm{S} 4-1=0.55 \mathrm{PA} / \mathrm{nm}^{2}\right.$ and $0.99 \mathrm{Si}^{4+} /$ $\mathrm{nm}^{2}$; S6-1 $=0.11 \mathrm{PA} / \mathrm{nm}^{2}$ and $\left.1.96 \mathrm{Si}^{4+} / \mathrm{nm}^{2}\right)$ systems. All spectra were obtained after 1 day of reaction in aqueous suspensions of 50 $\mathrm{m}^{2} / \mathrm{L}$ goethite in $10 \mathrm{mM} \mathrm{NaCl}$ at $298 \mathrm{~K}$. All intensities were normalized for the bulk $\mathrm{Fe}-\mathrm{O}-\mathrm{H}$ bending region (Figure S2). To obtain spectral profiles of PA only in (b), (i) the bending band of liquid water $\left(\sim 1630 \mathrm{~cm}^{-1}\right)$ was removed from the spectrum of wet unreacted goethite and (ii) the combination $\left(1662 \mathrm{~cm}^{-1}\right)$ and overtones $\left(1789 \mathrm{~cm}^{-1}\right)$ of $\mathrm{Fe}-\mathrm{O}-\mathrm{H}$ bending modes were removed from the spectra of dry goethite (cf. Figure S8 for uncorrected spectra). The spectral profile of $\mathrm{HB}$ species was obtained from the spectrum at $\mathrm{pH} 6$, and the spectral profile of $\mathrm{MB}$ species was obtained by subtracting the spectrum at $\mathrm{pH} 4$ from the spectrum at $\mathrm{pH} 6$.

$$
\begin{aligned}
2 & \equiv \mathrm{FeOH}^{-0.5}+4 \mathrm{Si}(\mathrm{OH})_{4}{ }^{0} \\
& \rightleftharpoons(\equiv \mathrm{FeO})_{2} \mathrm{SiHSi}_{3} \mathrm{O}_{4}(\mathrm{OH})_{8}{ }^{-2}+\mathrm{H}^{+}+4 \mathrm{H}_{2} \mathrm{O}
\end{aligned}
$$

The model predicts polymeric species at silicate loadings exceeding $\sim 0.9 \mathrm{Si}^{4+} / \mathrm{nm}^{2}$ at $\mathrm{pH} 4$ and $\sim 1.1 \mathrm{Si}^{4+} / \mathrm{nm}^{2}$ at $\mathrm{pH} 6$ (Figure S5). This is supported further by FTIR spectroscopy ${ }^{13}$ where the $\mathrm{Si}-\mathrm{O}$ band characteristic of $\mathrm{Si}-\mathrm{O}-\mathrm{Si}$ linkages appears in samples where bands of $-\mathrm{OH}$ groups were already consumed (Figure S3). We also note that, from an electrostatic standpoint (Figure S6), silicate binding lowered the outerHelmholtz potentials by $\sim 0.03-0.04 \mathrm{~V}$ throughout the entire $\mathrm{pH}$ range and lowered the point of zero charge from 9.1 to 8.3. Silicate binding therefore intrinsically weakened the electrostatically driven binding of organic species on goethite.

PA binding was predicted using a recalibration of our previous SCM model (Table 1) involving hydrogen-bonded (HB) and metal-bonded (MB) species (Figure 1).,31 FTIR spectra confirmed our previous findings ${ }^{30,31}$ supporting the predominance of $\mathrm{HB}$ complexes at $\mathrm{pH} 6$ and the coexistence of both complexes at $\mathrm{pH} 4$ (Figure $4 \mathrm{~b}$ and Figures S7 and S8). $\mathrm{HB}$ species formed direct hydrogen bonds between carboxyl groups and surface $\mathrm{OH}$ groups, and $\mathrm{MB}$ complexes formed direct $\mathrm{Fe}-$ carboxylate bonds after ligand exchange with $\mathrm{OH}$ groups (Figure 1). The primary involvement of (singly coordinated) $-\mathrm{OH}$ groups in the formation of these species was confirmed by FTIR of dried goethite through the preferential loss of the signature $3661 \mathrm{~cm}^{-1}$ band of $-\mathrm{OH}$ (Figure $3 \mathrm{~b}$ for $\mathrm{pH} 6$ and Figure $\mathrm{S} 4$ for $\mathrm{pH} 4$ ) with PA loadings. These spectra also revealed that the remaining unreacted $-\mathrm{OH}$ groups were more strongly hydrogen-bonded. This can be appreciated by a broad and low-lying band at lower $\mathrm{O}-\mathrm{H}$ stretching frequencies $\left(\sim 3575-3650 \mathrm{~cm}^{-1}\right)$ appearing at high PA loadings (Figure $3 \mathrm{~b}$ ). Ideally, the steric constraints at the dominant (101) plane should promote bridging between two Fe atoms separated by $\sim 3 \AA$ from one another (Figure 1), ${ }^{33}$ while at the (210) plane two $\equiv \mathrm{FeOH}^{-0.5}$ should be located on the same $\mathrm{Fe}$ (III) octahedron. As such, we modeled PA binding as a $1: 2 \mathrm{PA} / \equiv \mathrm{FeOH}^{-0.5}$ species as follows:

$$
\begin{aligned}
& 2 \mathrm{H}^{+}+2 \equiv \mathrm{FeOH}^{-0.5}+\mathrm{PA}^{-2} \rightleftharpoons\left(\equiv \mathrm{FeOH}_{2}\right)_{2}(\mathrm{PA})^{-} \\
& 2 \mathrm{H}^{+}+2 \equiv \mathrm{FeOH}^{-0.5}+\mathrm{PA}^{-2} \rightleftharpoons(\equiv \mathrm{Fe})_{2}(\mathrm{PA})^{-}+2 \mathrm{H}_{2} \mathrm{O}
\end{aligned}
$$

Of note, the charge-distribution and capacitance values of the compact layers (Table 1) generated the $\mathrm{pH}$-dependent loadings of these species ${ }^{34}$ (Figure S7c) and lowered outerHelmholtz (1-plane) potentials by up to $\sim 0.1 \mathrm{~V}$ below $\mathrm{pH} \sim 8$ (Figure S6). Our recalibrated model (Figure 2 and Figure S6) predicts the $\mathrm{pH}$ - and concentration-dependent $\mathrm{PA}$ loadings (Table 1). ${ }^{30}$

Using these subsystem models, we explored a new model for the competitive binding of PA and silicate on goethite. This search involved various hydrogen-bonded interactions between coexisting PA and silicate complexes bound to vicinal (exchanged) $-\mathrm{OH}$ groups. However, the simplest and most accurate model predicting the adsorption data (Figures 2, 5,
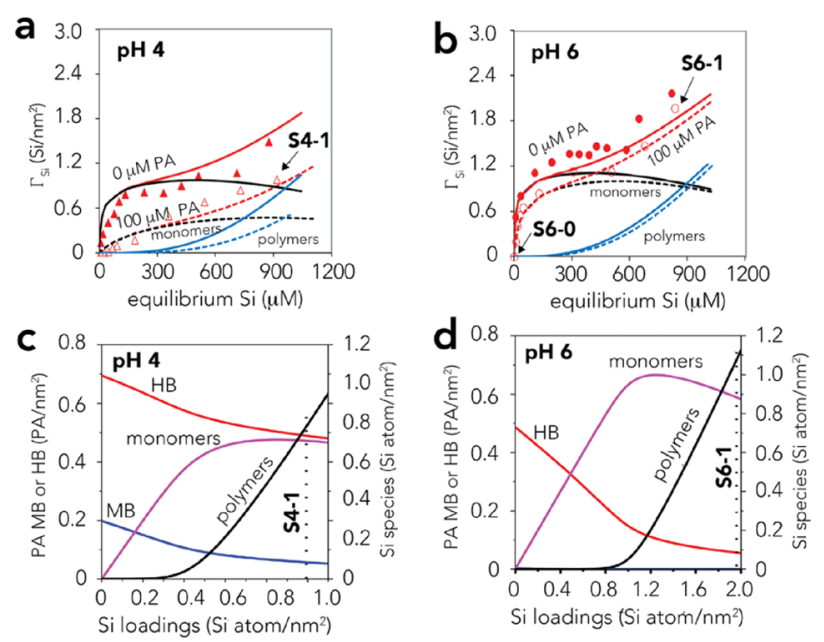

Figure 5. (a, b) Silicate adsorption isotherms and (c, d) speciation from competitive model predictions at $\mathrm{pH} 4$ and 6. Conditions for samples S4-1 and S6-1, for which the FTIR spectra are shown in Figure $4 \mathrm{~b}$, are indicated by $(\mathrm{a}, \mathrm{b})$ the arrow pointing to data points and $(c, d)$ the vertical dotted lines.

and 6) was generated from the subsystem model predictions alone. As such, the model predicts PA and silicate binding in terms of (i) the competition for $-\mathrm{OH}$ groups without involving $\mathrm{PA} /$ silicate interactions and (ii) a concomitant lowering of positive 1- and 2-plane electrostatic potentials by these anions (Figure $6 \mathrm{f}$ and Figure S6). The competition for $-\mathrm{OH}$ groups aligns with the $\mathrm{O}-\mathrm{H}$ stretching region of goethite (Figure 3c), chiefly revealing the same spectral features as in the subsystems (Figure 3a,b). However, we note that nearly equimolar loadings of PA and silicate $\left(\Gamma_{\mathrm{PA}} \approx \Gamma_{\mathrm{Si}} \approx\right.$ 0.4 species $/ \mathrm{nm}^{2}$ ) red-shifted the $3661 \mathrm{~cm}^{-1}$ band to $\sim 3640$ $\mathrm{cm}^{-1}$. Although this idea needs further support (e.g., by molecular modeling), this newly resolved band could indicate a regular spatial distribution of $\mathrm{PA}$ and silicate species along rows of exchanged and unreacted $-\mathrm{OH}$ groups (Figure 1).

The model thus predicted PA removal by the concomitant loss of both $\mathrm{HB}$ and $\mathrm{MB}$ species under acidic conditions and by the loss of $\mathrm{HB}$ species at circumneutral $\mathrm{pH}$ (Figure $5 \mathrm{c}, \mathrm{d}$ ). At $\mathrm{pH} 4$, the model predicted no clear preferential removal of 

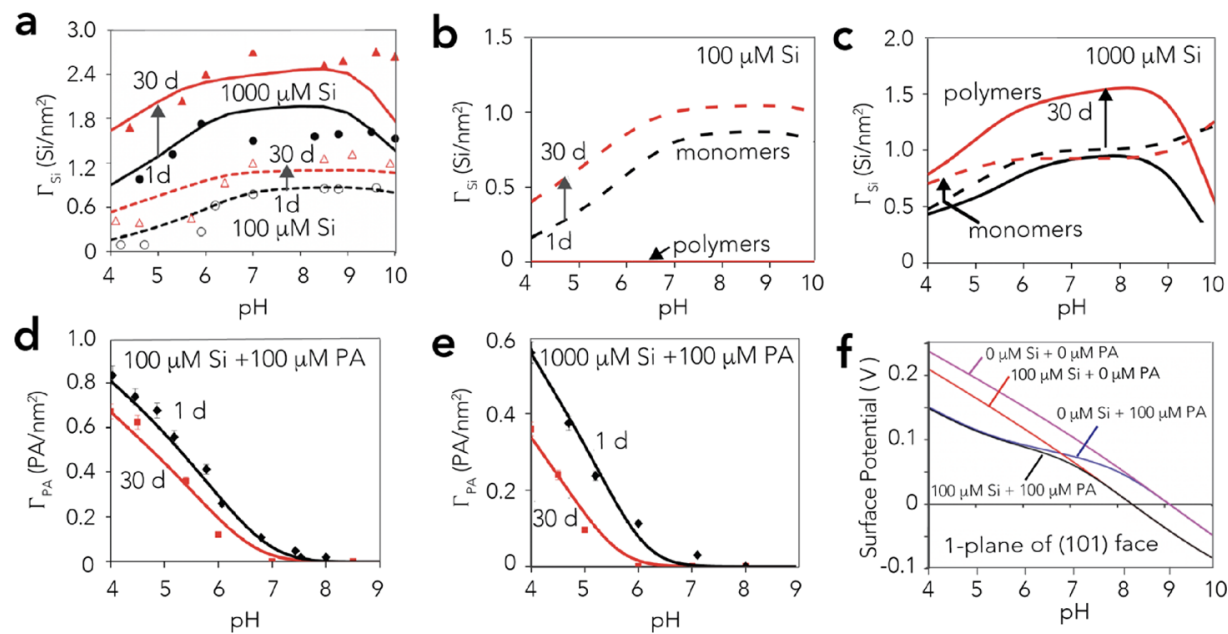

Figure 6. Batch adsorption data and SCM modeling. (a-c) Silicate loadings, (d, e) PA loadings, and (f) surface electrostatic potentials achieved in suspensions of $50 \mathrm{~m}^{2} / \mathrm{L}$ goethite in $10 \mathrm{mM} \mathrm{NaCl}$ at $298 \mathrm{~K}$. (a-e) Comparison of experimental and predicted SCM loadings achieved at 1 day (black) and 30 days (red) of reaction time in competitive systems with total concentrations of $100 \mu \mathrm{M} \mathrm{PA}$ with (a, b, d) 100 or (a, c, e) $1000 \mu \mathrm{M}$ silicate. (f) Predicted surface potentials of the 1-plane of the (101) face of goethite containing unbound silicate oxo groups and carboxyl groups of HB PA species (Table 1; cf. Figure S6 for full modeling results).

HB species over MB species (Figure 5c) as silicate binding also targeted the same $-\mathrm{OH}$ groups needed for PA species formation. Speciation changes predicted by the model also align with FTIR spectra of wet goethite pastes at $\mathrm{pH} 4$ and 6 (Figure $4 \mathrm{~b}$ ). There, we found that decreased band intensities of PA species associated with silicate uptake did not alter the spectral profiles. Most notably, the symmetric $\mathrm{C}-\mathrm{O}$ stretching band of PA $\left(\nu_{\mathrm{CO}, \text { sym }}\right)$ remained centered at $1408 \mathrm{~cm}^{-1}$, while a preferential removal of $\mathrm{HB}$ over $\mathrm{MB}$ species would have shifted this band to $1412 \mathrm{~cm}^{-1}$ (Figure S8). ${ }^{31}$

Model predictions also involved polymeric silicate species to explain additional loadings achieved at the greatest concentrations under study and where PA loadings remained unchanged (e.g., Figure 2c). Polymeric species appeared at silicate loadings exceeding $\sim 0.4 \mathrm{Si}^{4+} / \mathrm{nm}^{2}$ at $\mathrm{pH} 4$ and $\sim 0.8$ $\mathrm{Si}^{4+} / \mathrm{nm}^{2}$ at $\mathrm{pH} 6$ (Figure $5 \mathrm{c}, \mathrm{d}$ ). The conditions correspond to dissolved silicate concentrations of $\sim 300 \mu \mathrm{M}$ (Figure 5a,b). Accordingly, the $\mathrm{Si}-\mathrm{O}$ stretching region (Figure $4 \mathrm{a}$ ) revealed coexisting monomeric and polymeric species. The model even aligns with the apparent decrease in polymeric species at $\mathrm{pH} 4$ (S4-1; Figure 4a) resulting from the competitive binding of MB PA species, and with relatively unchanged polymer loadings at $\mathrm{pH} 6$ (cf. Figure 2c).

3.2. Aging. To investigate further the potential impact that silicate polymers could have on PA loadings, we used our model to predict loadings achieved after 30 days of reaction time (Figure 6). This reaction time was chosen based on our previous work ${ }^{13}$ showing the development of silicate polymeric species on goethite. These efforts at two environmentally relevant silicate concentrations $(100$ and $1000 \mu \mathrm{M})$ revealed larger silicate loadings over the entire $\mathrm{pH}$ range $(\mathrm{pH} 4-10)$ without, however, any substantial changes in the shape of the adsorption envelope (Figure 6). For example, the maximum silicate loadings increased from $\sim 0.9$ to $\sim 1.3 \mathrm{Si}^{4+} / \mathrm{nm}^{2}$ for 100 $\mu \mathrm{M}$ silicate and from $\sim 1.6$ to $\sim 2.7 \mathrm{Si}^{4+} / \mathrm{nm}^{2}$ for $1000 \mu \mathrm{M}$ silicate solutions reacted with $50 \mathrm{~m}^{2} / \mathrm{L}$ goethite (Figure 6). The most effective and simple approach to account for these loadings was to raise all silicate binding constants by $0.8-1.7$ $\log K$ unit from the values that we obtained at 1 day reaction time (Figure 2 and Table 1). The resulting model predicted a $\sim 2.3$-fold increase in monomeric and $\sim 1.8$-fold increase in polymeric species after 30 days of reaction time and therefore reflects the longer-term reaction needed for silicate binding on goethite. In this sense, we treat binding of all other species to be in dynamic equilibrium in relation to silicate binding. Accordingly, the model predicts that solutions of $100 \mu \mathrm{M}$ silicate only decreased PA loadings when monomeric species increased. However, the formation of polymeric species was more significant in solutions of $1000 \mu \mathrm{M}$ silicate. Because greater concentrations of these species consumed an even greater number of reactive sites (cf. chemical speciation in Figure $6 \mathrm{c}$ and Figure S5) and because they lowered electrostatic potentials (Figure 6f), PA loadings were also lowered.

3.3. Drying. Finally, to explore the fate of these coexisting PA and silicate species exposed to drying, we studied the FTIR spectral profiles of dehydrated goethite particles previously reacted for 1 day in mixed aqueous solutions of PA and silicate (Figure 7). To assist this task, we first identified the predominant molecular species of PA produced by drying. A chemometric analysis with these new FTIR spectra (Section 2.5) showed that $\mathrm{HB}$ and $\mathrm{MB}$ species persisted to the dry state. However, the removal of water facilitated the formation of $\mathrm{MB}$ over $\mathrm{HB}$ species, as can be appreciated by the PA species loadings shown in Figure 7d (See Figure S7 for comparison with speciation in contact with liquid water). This analysis extracted two forms of $\mathrm{HB}$ (HB1 and HB2) species, mostly with different breadths in the asymmetric $\mathrm{C}-\mathrm{O}$ stretching $\left(\nu_{\mathrm{CO} \text {,asym }}\right)$ region. These differences relate to differences in inhomogeneous band broadening caused by hydrogen-bonded interactions with surface $\mathrm{OH}$ groups of contrasting $\mathrm{O}-\mathrm{H}$ bond strength. The species with the narrower $\nu_{\mathrm{CO} \text {,asym }}$ region $(\mathrm{HB} 1)$ predominates only at low PA loadings, as PA likely targets a collection of surface $\mathrm{OH}$ groups with a narrower distribution of $\mathrm{O}-\mathrm{H}$ bond strength (Figure 1). The consumption of these groups at larger PA loadings, however, favors interactions with other $\mathrm{OH}$ groups with a broader range of $\mathrm{O}-\mathrm{H}$ bond strengths (HB2). These $\mathrm{OH}$ groups likely include $\mu-\mathrm{OH}$ and various $\mu_{3^{-}}$ $\mathrm{OH}$ groups of the goethite surface (Figure 1). 

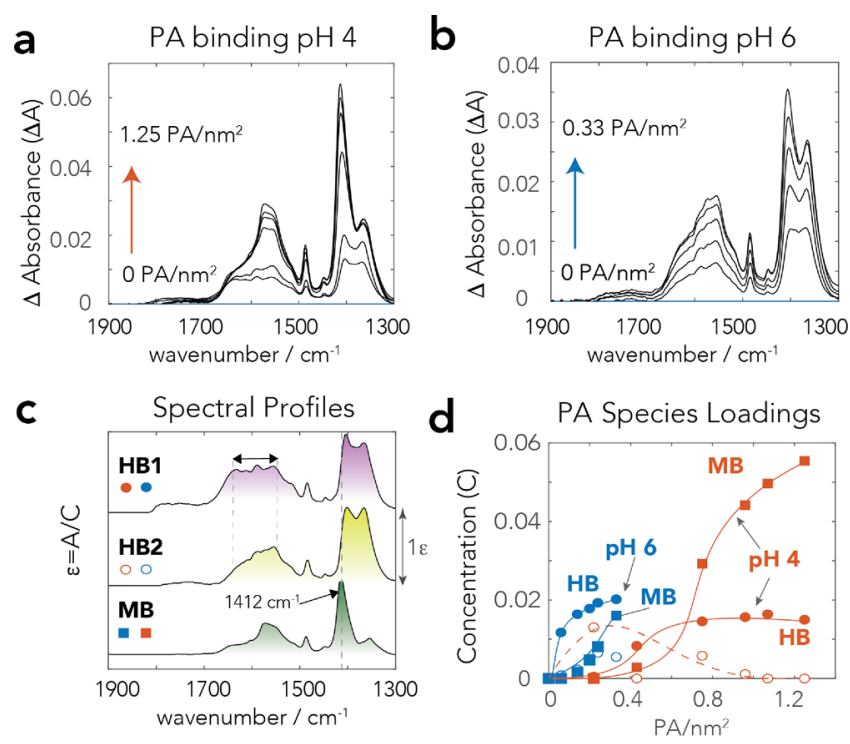

Figure 7. Net ATR-FTIR spectra of PA bound to $\mathrm{N}_{2}$-dry $(298 \mathrm{~K}$ ) goethite with removed contributions from overtones and combinations of goethite bulk bending modes (cf. Figure S8 for uncorrected spectra). Samples were initially reacted in $50 \mathrm{~m}^{2} / \mathrm{L}$ suspensions of goethite in $10 \mathrm{mM} \mathrm{NaCl}$ at $298 \mathrm{~K}$ with $0-800 \mu \mathrm{M} \mathrm{PA}$ at pH (a) 4 and (b) 6 for 1 day and then dried under a stream of $\mathrm{N}_{2}(\mathrm{~g})$. Increased loadings are isotherms at these fixed $\mathrm{pH}$ values. Chemometric (MCR) analyses decomposed these spectra $(A)$ into $(c) \varepsilon$ (n.b. normalized arbitrary scale) and (d) concentration (C) profiles shown in (b) such that $A=\varepsilon \times C$. Lines in (d) are only visual guides to the data for which the legends are shown in (c).

As in our batch adsorption data (Figure 2), FTIR spectra of dry goethite at $\mathrm{pH} 4$ and 6 (Figure $8 \mathrm{a}, \mathrm{b}$ ) after reaction in the competitive system reflected the systematic loss of PA loadings resulting from silicate binding. A chemometric analysis of the $\mathrm{C}-\mathrm{O}$ stretching region extracted only one dominant $\mathrm{HB}$ PA species comparable to HB2 (Figure 7) but now with a new MB-like species (MB2), with the spectral profile shown in Figure $8 \mathrm{c}$. The new MB2 species replaced up to $\sim 1 / 3$ of the original $\mathrm{MB}$ species at $\mathrm{pH} 4$. At $\mathrm{pH} 6$, however, the absence of water facilitated the replacement of $\mathrm{HB}$ by $\mathrm{MB} 2$, and by a more minor fraction of $\mathrm{MB}$ species the previously coexisting $\mathrm{MB}$ and $\mathrm{HB} 1 / \mathrm{HB} 2$ species at $\mathrm{pH} 6$ (Figure $8 \mathrm{~d}, \mathrm{e}$ ). We contend that the loss of water broadened the $\nu_{\mathrm{CO} \text {,asym }}$ region of $\mathrm{MB} 2$ over a considerably larger range of frequencies than in $\mathrm{MB}$ (Figure 7c). This silicate-induced inhomogeneous band broadening could thereby suggest that MB2 species interacted with $\mathrm{OH}$ groups with a broader range of $\mathrm{O}-\mathrm{H}$ bond strengths/acidities than on dry goethite in the absence of silicates (Figure 7). This spectral profile may even possibly arise from interactions with neighboring unreacted goethite hydroxo, and with $\mathrm{Si}-\mathrm{OH}$ groups of co-sorbed silicate species.

These results consequently showed that drying facilitated the formation of MB species of PA in the presence of bound silicate. These bound silicates remained predominantly in the form of monomeric species when loadings were at least up to $1.12 \mathrm{Si}^{4+} / \mathrm{nm}^{2}$ (Figure $8 \mathrm{f}$ ). Additional polymeric species did not appear because of the low concentrations of unbound silicate species in the wet goethite pastes prior drying. As such, our finding that dry goethite predominantly exposed coexisting MB PA species with monomeric silicate species even aligns with our SCM model of wet goethite pastes from which these products were made. We find these results encouraging for pursuing future studies dedicated to bridging the speciation of wet and dry interfacial systems, which are becoming crucial for understanding how wet/dry cycling impacts competitive binding at mineral surfaces.

\section{CONCLUSIONS}

This batch adsorption, ATR-FTIR spectroscopy, and surface complexation modeling study revealed the $\mathrm{pH}$-, concentration-,
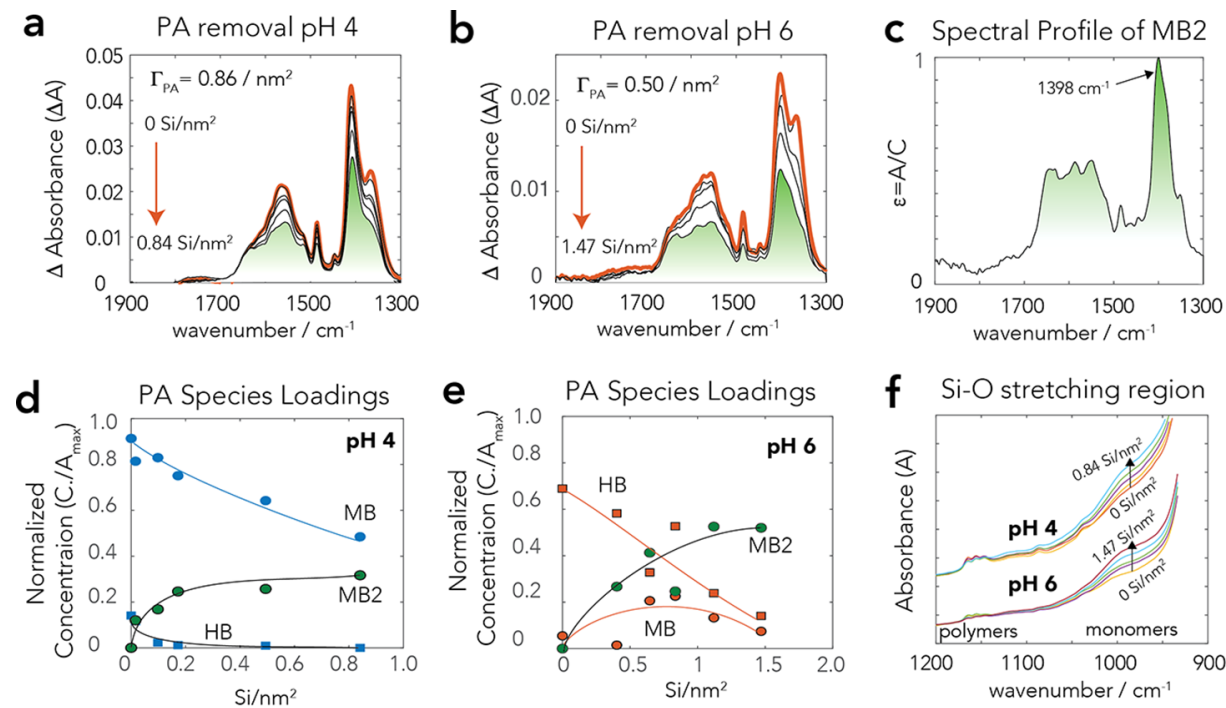

Figure 8. ATR-FTIR spectra and chemometric (MCR) analyses of $\mathrm{N}_{2}$-dry $(298 \mathrm{~K})$ goethite initially reacted in $50 \mathrm{~m}^{2} / \mathrm{L}$ suspensions in $10 \mathrm{mM}$ $\mathrm{NaCl}$ at $298 \mathrm{~K}$ (cf. Figure S8 for uncorrected spectra). (a, b) Spectra at pH (a) 4 and (b) 6 at various PA loadings with $100 \mu \mathrm{M} \mathrm{PA}$ and $0-1000$ $\mu \mathrm{M}$ Si. Note that combination $\left(1662 \mathrm{~cm}^{-1}\right)$ and overtones $\left(1789 \mathrm{~cm}^{-1}\right)$ of $\mathrm{Fe}-\mathrm{O}-\mathrm{H}$ bending modes (Figure S8) were removed. Decreased PA loadings result from the competitive binding of silicate at these fixed $\mathrm{pH}$ values. (c-e) Chemometric analyses used concentration profiles of $\mathrm{HB}$ and $\mathrm{MB}$ of Figure 7 to also extract (c) the spectral profile of a new component, $\mathrm{PA}-\mathrm{Si}$. The associated concentration profiles of these three species reveal the predominant removal of (d) $\mathrm{MB}$ species at $\mathrm{pH} 4$ but of (e) HB species at $\mathrm{pH}$ 6. Lines in (d) and (e) are only visual guides. (f) The Si-O stretching region in corresponding spectra of $(a)$ and $(b)$ showing the preferential appearance of monomeric silicate species. 
and time-dependent competitive binding of silicate ions and PA on goethite. Our surface complexation model can now adequately predict competitive binding for reactive $-\mathrm{OH}$ functional groups of the goethite surface only using formation constants of $\mathrm{HB} / \mathrm{MB} \mathrm{PA}$ species and monomeric/polymeric silicate species obtained from subsystems and whose presence was assessed by ATR-FTIR spectroscopy. The model can also account for the more effective competition of silicate species after 30 days of reaction time by a greater concentration of monomeric silicate species at low $(100 \mu \mathrm{M})$ and of polymeric species at high $(1000 \mu \mathrm{M})$ silicate concentrations. It also provides an adequate description of silicate and PA loadings over a wide range of concentrations, and $\mathrm{pH}$ values.

Dehydration altered the molecular scale speciation of coexisting PA and silicate species. While both $\mathrm{HB}$ and $\mathrm{MB}$ species of PA persisted under the dry state, the removal of water favored $\mathrm{MB}$ over $\mathrm{HB}$ species. These findings are important for understanding the (geo)chemistry of unsaturated environments subject to water fluctuations, such as vadose zones of soils. As $\mathrm{MB}$ species bind more strongly to minerals than $\mathrm{HB}$ species, drying soils could facilitate the attachment of organics at mineral surfaces and therefore decrease the transport of organic contaminants in aquatic environments. In addition, drying could facilitate silicate polymerization and therefore the reactivity of minerals, ${ }^{13}$ decreasing the quantity of contaminants adsorbed by minerals. These findings consequently call for new models over a broader range of carboxylate-bearing organic contaminants to understand their fate in soils, especially those undergoing wetdry cycles. In particular, future studies on the wettability of carboxylate- and Si-coated minerals and rehydration reactions of, for example, $\mathrm{MB}$ organic species triggered by dehydration may be especially important for understanding the fate of organic contaminants in nature.

\section{ASSOCIATED CONTENT}

\section{SI Supporting Information}

The Supporting Information is available free of charge at https://pubs.acs.org/doi/10.1021/acs.langmuir.1c02261.

Goethite X-ray diffractogram; goethite FTIR spectra; silicate binding edges and $\mathrm{Si}-\mathrm{O}$ and $\mathrm{O}-\mathrm{H}$ stretching bands of corresponding species; thermodynamic modeling of monomeric and polymeric silicate species: PA adsorption edges and corresponding thermodynamic modeling; and FTIR spectra of bound PA (PDF)

\section{AUTHOR INFORMATION}

Corresponding Author

Jean-François Boily - Department of Chemistry, Umeå University, Umeå SE-901 87, Sweden; 이이.org/00000003-4954-6461; Email: jean-francois.boily@umu.se

\section{Authors}

Wei Cheng - College of Resources and Environmental Science, South-Central University for Nationalities, Wuhan 430074, P.R. China

Rémi Marsac - Université Rennes, Rennes F-35000, France

Khalil Hanna - Université Rennes, Rennes F-35708, France; Institut Universitaire de France (IUF), Paris 75231, France; (1) orcid.org/0000-0002-6072-1294

Complete contact information is available at: https://pubs.acs.org/10.1021/acs.langmuir.1c02261

\section{Notes}

The authors declare no competing financial interest.

\section{ACKNOWLEDGMENTS}

This work was supported by the Swedish Research Council (2020-04853) to J.-F.B and the CNRS (PICS 2018-2020) to K.H. and J.-F.B. W.C. was supported by the China Scholarship Council for a Ph.D. grant and by Rennes Métropole (France) for a mobility grant for an extended research visit at Umeå University. K.H. is also supported by the Institut Universitaire de France (IUF).

\section{REFERENCES}

(1) Cusanovich, M. A. The Chemistry of Silica (Iler, Ralph K.). J. Chem. Educ. 1980, 57, A324.

(2) Alvarez, R.; Sparks, D. L. Polymerization of Silicate Anions in Solutions at Low Concentrations. Nature 1985, 318, 649.

(3) Marmier, N.; Fromage, F. Sorption of Cs(I) on Magnetite in the Presence of Silicates. J. Colloid Interface Sci. 2000, 223, 83-88.

(4) Jordan, N.; Marmier, N.; Lomenech, C.; Giffaut, E.; Ehrhardt, J.J. Competition between Selenium (IV) and Silicic Acid on the Hematite Surface. Chemosphere 2009, 75, 129-134.

(5) Christl, I.; Brechbühl, Y.; Graf, M.; Kretzschmar, R. Polymerization of Silicate on Hematite Surfaces and Its Influence on Arsenic Sorption. Environ. Sci. Technol. 2012, 46, 13235-13243.

(6) Jordan, N.; Lomenech, C.; Marmier, N.; Giffaut, E.; Ehrhardt, J.J. Sorption of Selenium(IV) onto Magnetite in the Presence of Silicic Acid. J. Colloid Interface Sci. 2009, 329, 17-23.

(7) Luxton, T. P.; Eick, M. J.; Rimstidt, D. J. The Role of Silicate in the Adsorption/Desorption of Arsenite on Goethite. Chem. Geol. 2008, 252, 125-135.

(8) Hiemstra, T.; Barnett, M. O.; van Riemsdijk, W. H. Interaction of Silicic Acid with Goethite. J. Colloid Interface Sci. 2007, 310, 8-17.

(9) Cornell, R. M.; Giovanoli, R.; Schindler, P. W. Effect of Silicate Species on the Transformation of Ferrihydrite into Goethite and Hematite in Alkaline Media. Clays Clay Miner. 1987, 35, 21-28.

(10) Cismasu, A. C.; Michel, F. M.; Tcaciuc, P.; Brown, G. E., Jr. Properties of Impurity-Bearing Ferrihydrite III. Effects of Si on the Structure of 2-Line Ferrihydrite. Geochim. Cosmochim. Acta 2014, 133, $168-185$.

(11) Vempati, R. K.; Loeppert, R. H. Influence of Structural and Adsorbed Si on the Transformation of Synthetic Ferrihydrite. Clays Clay Miner. 1989, 273-279.

(12) Jordan, N.; Marmier, N.; Lomenech, C.; Giffaut, E.; Ehrhardt, J.-J. Sorption of Silicates on Goethite, Hematite, and Magnetite: Experiments and Modelling. J. Colloid Interface Sci. 2007, 312, 224229.

(13) Kanematsu, M.; Waychunas, G. A.; Boily, J.-F. Silicate Binding and Precipitation on Iron Oxyhydroxides. Environ. Sci. Technol. 2018, 52, 1827-1833.

(14) Rusch, B.; Hanna, K.; Humbert, B. Coating of Quartz Silica with Iron Oxides: Characterization and Surface Reactivity of Iron Coating Phases. Colloids Surf., A 2010, 353, 172-180.

(15) Davis, C. C.; Chen, H.-W.; Edwards, M. Modeling Silica Sorption to Iron Hydroxide. Environ. Sci. Technol. 2002, 36, 582-587.

(16) Kersten, M.; Vlasova, N. Silicate Adsorption by Goethite at Elevated Temperatures. Chem. Geol. 2009, 262, 336-343.

(17) Hiemstra, T. Ferrihydrite Interaction with Silicate and Competing Oxyanions: Geometry and Hydrogen Bonding of Surface Species. Geochim. Cosmochim. Acta 2018, 238, 453-476.

(18) Gao, X.; Root, R. A.; Farrell, J.; Ela, W.; Chorover, J. Effect of Silicic Acid on Arsenate and Arsenite Retention Mechanisms on 6-L Ferrihydrite: A Spectroscopic and Batch Adsorption Approach. Appl. Geochem. 2013, 38, 110-120.

(19) Ferras, Y.; Robertson, J.; Swedlund, P. J. The Application of Raman Spectroscopy to Probe the Association of $\mathrm{H} 4 \mathrm{SiO} 4$ with Iron Oxides. Aquat. Geochem. 2017, 23, 21-31. 
(20) Swedlund, P. J.; Miskelly, G. M.; McQuillan, A. J. An Attenuated Total Reflectance IR Study of Silicic Acid Adsorbed onto a Ferric Oxyhydroxide Surface. Geochim. Cosmochim. Acta 2009, 73, 4199-4214.

(21) Zhou, L.; Cheng, W.; Marsac, R.; Boily, J.-F.; Hanna, K. Silicate Surface Coverage Controls Quinolone Transport in Saturated Porous Media. J. Colloid Interface Sci. 2022, 607, 347-356.

(22) Meng, X.; Korfiatis, G. P.; Bang, S.; Bang, K. W. Combined Effects of Anions on Arsenic Removal by Iron Hydroxides. Toxicol. Lett. 2002, 133, 103-111.

(23) Swedlund, P. Adsorption and Polymerisation of Silicic Acid on Ferrihydrite, and Its Effect on Arsenic Adsorption. Water Res. 1999, $33,3413-3422$.

(24) Rusch, B.; Hanna, K.; Humbert, B. Sorption and Transport of Salicylate in a Porous Heterogeneous Medium of Silica Quartz and Goethite. Environ. Sci. Technol. 2010, 44, 2447-2453.

(25) Roonasi, P.; Yang, X.; Holmgren, A. Competition between Sodium Oleate and Sodium Silicate for a Silicate/Oleate Modified Magnetite Surface Studied by in Situ ATR-FTIR Spectroscopy. J. Colloid Interface Sci. 2010, 343, 546-552.

(26) Yeasmin, S.; Singh, B.; Kookana, R. S.; Farrell, M.; Sparks, D. L.; Johnston, C. T. Influence of Mineral Characteristics on the Retention of Low Molecular Weight Organic Compounds: A Batch Sorption-Desorption and ATR-FTIR Study. J. Colloid Interface Sci. 2014, 432, 246-257.

(27) Hu, S.; Wu, Y.; Li, F.; Shi, Z.; Ma, C.; Liu, T. Fulvic AcidMediated Interfacial Reactions on Exposed Hematite Facets during Dissimilatory Iron Reduction. Langmuir 2021, 37, 6139-6150.

(28) Marsac, R.; Martin, S.; Boily, J.-F.; Hanna, K. Oxolinic Acid Binding at Goethite and Akaganéite Surfaces: Experimental Study and Modeling. Environ. Sci. Technol. 2016, 50, 660-668.

(29) Cheng, W.; Kalahroodi, E. L.; Marsac, R.; Hanna, K. Adsorption of Quinolone Antibiotics to Goethite under Seawater Conditions: Application of a Surface Complexation Model. Environ. Sci. Technol. 2019, 53, 1130-1138.

(30) Hanna, K.; Martin, S.; Quilès, F.; Boily, J.-F. Sorption of Phthalic Acid at Goethite Surfaces under Flow-Through Conditions. Langmuir 2014, 30, 6800-6807.

(31) Boily, J.-F.; Persson, P.; Sjöberg, S. Benzenecarboxylate Surface Complexation at the Goethite $(\alpha-\mathrm{FeOOH}) /$ Water Interface: II. Linking IR Spectroscopic Observations to Mechanistic Surface Complexation Models for Phthalate, Trimellitate, and Pyromellitate. Geochim. Cosmochim. Acta 2000, 64, 3453-3470.

(32) Eick, M. J.; Luxton, T. P.; Welsh, H. A. Effect of Silica Polymerization on the Oxalate-Promoted Dissolution of Goethite. Clays Clay Miner. 2009, 57, 578-585.

(33) Boily, J.-F.; Kozin, P. A. Particle Morphological and Roughness Controls on Mineral Surface Charge Development. Geochim. Cosmochim. Acta 2014, 141, 567-578.

(34) Boily, J.-F.; Persson, P.; Sjöberg, S. Benzenecarboxylate Surface Complexation at the Goethite $(\alpha-\mathrm{FeOOH}) /$ Water Interface. J. Colloid Interface Sci. 2000, 227, 132-140.

(35) Masuyama, H.; Hiramatsu, Y.; Kunitomi, M.; Kudo, T.; MacDonald, P. N. Endocrine Disrupting Chemicals, Phthalic Acid and Nonylphenol, Activate Pregnane X Receptor-Mediated Transcription. Mol. Endocrinol. 2000, 14, 421-428.

(36) Paluselli, A.; Fauvelle, V.; Galgani, F.; Sempéré, R. Phthalate Release from Plastic Fragments and Degradation in Seawater. Environ. Sci. Technol. 2019, 53, 166-175.

(37) Tan, W.; Zhang, Y.; He, X.; Xi, B.; Gao, R.; Mao, X.; Huang, C.; Zhang, H.; Li, D.; Liang, Q.; Cui, D.; Alshawabkeh, A. N. Distribution Patterns of Phthalic Acid Esters in Soil Particle-Size Fractions Determine Biouptake in Soil-Cereal Crop Systems. Sci. Rep. 2016, 6, 31987.

(38) Abdel Daiem, M. M.; Rivera-Utrilla, J.; Ocampo-Pérez, R.; Méndez-Díaz, J. D.; Sánchez-Polo, M. Environmental Impact of Phthalic Acid Esters and Their Removal from Water and Sediments by Different Technologies - A Review. J. Environ. Manage. 2012, 109, 164-178.
(39) Net, S.; Sempéré, R.; Delmont, A.; Paluselli, A.; Ouddane, B. Occurrence, Fate, Behavior and Ecotoxicological State of Phthalates in Different Environmental Matrices. Environ. Sci. Technol. 2015, 49, 4019-4035.

(40) Liu, H.; Chen, T.; Frost, R. L. An Overview of the Role of Goethite Surfaces in the Environment. Chemosphere 2014, 103, 1-11.

(41) Song, X.; Boily, J.-F. Structural Controls on OH Site Availability and Reactivity at Iron Oxyhydroxide Particle Surfaces. Phys. Chem. Chem. Phys. 2012, 14, 2579-2586.

(42) Mian, S. A.; Yang, L.-M.; Saha, L. C.; Ahmed, E.; Ajmal, M.; Ganz, E. A Fundamental Understanding of Catechol and Water Adsorption on a Hydrophilic Silica Surface: Exploring the Underwater Adhesion Mechanism of Mussels on an Atomic Scale. Langmuir 2014, 30, 6906-6914.

(43) Altun, A. O.; Bond, T.; Pronk, W.; Park, H. G. Sensitive Detection of Competitive Molecular Adsorption by Surface-Enhanced Raman Spectroscopy. Langmuir 2017, 33, 6999-7006.

(44) Newcomb, C. J.; Qafoku, N. P.; Grate, J. W.; Bailey, V. L.; De Yoreo, J. J. Developing a Molecular Picture of Soil Organic MatterMineral Interactions by Quantifying Organo-Mineral Binding. Nat. Commun. 2017, 8, 396.

(45) Tian, S.; Wang, T.; Li, G.; Sheng, M.; Zhang, P. Nanoscale Surface Properties of Organic Matter and Clay Minerals in Shale. Langmuir 2019, 35, 5711-5718.

(46) Awad, A. M.; Shaikh, S. M. R.; Jalab, R.; Gulied, M. H.; Nasser, M. S.; Benamor, A.; Adham, S. Adsorption of Organic Pollutants by Natural and Modified Clays: A Comprehensive Review. Sep. Purif. Technol. 2019, 228, 115719.

(47) Dziadkowiec, J.; Røyne, A. Nanoscale Forces between Basal Mica Surfaces in Dicarboxylic Acid Solutions: Implications for Clay Aggregation in the Presence of Soluble Organic Acids. Langmuir 2020, 36, 14978-14990.

(48) Thissen, P. Exchange Reactions at Mineral Interfaces. Langmuir 2020, 36, 10293-10306.

(49) Sit, I.; Sagisaka, S.; Grassian, V. H. Nucleotide Adsorption on Iron(III) Oxide Nanoparticle Surfaces: Insights into Nano-Geo-Bio Interactions Through Vibrational Spectroscopy. Langmuir 2020, 36, 15501-15513.

(50) Halasz, I.; Agarwal, M.; Li, R.; Miller, N. Vibrational Spectra and Dissociation of Aqueous $\mathrm{Na} 2 \mathrm{SiO} 3$ Solutions. Catal. Lett. 2007, $117,34-42$.

(51) Gaboriaud, F.; Ehrhardt, J.-J. Effects of Different Crystal Faces on the Surface Charge of Colloidal Goethite $(\alpha-\mathrm{FeOOH})$ Particles: An Experimental and Modeling Study. Geochim. Cosmochim. Acta 2003, 67, 967-983.

(52) Greenberg, A. E.; Clesceri, L.S; Eaton, A.D. Standard Methods for the Examination of Water and Wastewater; 18. ed., American Public Health Association: Washington, 1992; p 326.

(53) Jaumot, J.; Gargallo, R.; de Juan, A.; Tauler, R. A Graphical User-Friendly Interface for MCR-ALS: A New Tool for Multivariate Curve Resolution in MATLAB. Chemom. Intell. Lab. Syst. 2005, 76, $101-110$.

(54) Hiemstra, T.; Van Riemsdijk, W. H. A Surface Structural Approach to Ion Adsorption: The Charge Distribution (CD) Model. J. Colloid Interface Sci. 1996, 179, 488-508.

(55) Parkhurst, D. L.; Appelo, C. A. J. User's Guide to PHREEQC (Version 2): A Computer Program for Speciation, Batch-Reaction, OneDimensional Transport, and Inverse Geochemical Calculations; WaterResources Investigations Report 99-4259; U.S. Geological Survey, 1999; p 312. 